Review

\title{
Reactivation of Hepatitis B Virus in Patients with Multiple Myeloma
}

\author{
Yutaka Tsukune, Makoto Sasaki * and Norio Komatsu \\ Department of Hematology, Juntendo University School of Medicine, 2-1-1 Hongo, Bunkyo-Ku, \\ Tokyo 113-8421, Japan; yu-tsuku@juntendo.ac.jp (Y.T.); komatsun@juntendo.ac.jp (N.K.) \\ * Correspondence: msasaki@juntendo.ac.jp; Tel.: +81-3-3813-3111
}

Received: 5 October 2019; Accepted: 17 November 2019; Published: 19 November 2019 updates

\begin{abstract}
Reactivation of hepatitis B virus (HBV) is a well-known complication in patients with hematological malignancies during or after cytotoxic chemotherapy. If the initiation of antiviral therapy is delayed in patients with HBV reactivation, these patients can develop severe hepatitis and may die of fulminant hepatitis. The preventive strategy for HBV reactivation in patients with malignant lymphoma has already been established based on some prospective studies. As there was an increased number of novel agents being approved for the treatment of multiple myeloma (MM), the number of reported cases of HBV reactivation among MM patients has gradually increased. We conducted a Japanese nationwide retrospective study and revealed that HBV reactivation in MM patients is not rare and that autologous stem cell transplantation is a significant risk factor. In this study, around $20 \%$ of all patients with HBV reactivation developed HBV reactivation after 2 years from the initiation of therapy, unlike malignant lymphoma. This might be due to the fact that almost all of the patients received chemotherapy for a long duration. Therefore, a new strategy for the prevention of $\mathrm{HBV}$ reactivation in MM patients is required.
\end{abstract}

Keywords: hepatitis B virus; reactivation; multiple myeloma; novel agents; autologous stem cell transplantation

\section{Introduction}

An estimated 2 billion people worldwide have evidence of either current or past hepatitis B virus (HBV) infection, including 257 million people with chronic HBV infection (HBV carriers), who are defined as testing positive for hepatitis B surface antigen (HBsAg) [1,2]. Specifically, the prevalence of past HBV infection is particularly high in Asia (Japan: $23.2 \%$, China: $20.1 \%$, Singapore: $34.3 \%$, Hong Kong: 44.2-62.0\%) [3]. HBV reactivation is a well-known complication in patients with hematological malignancies during or after cytotoxic chemotherapy. HBV reactivation is caused by regrowth of HBV in the body, and it can induce severe flares of hepatitis, which can in turn lead to fatal fulminant hepatitis [4]. HBV reactivation has mainly been observed in HBV carriers who were receiving cancer chemotherapy [4,5]. On the other hand, HBV reactivation is also known to occur in patients with resolved HBV infection, with resolution being defined as testing negative for HBsAg but positive for antibodies against hepatitis B core antigen (anti-HBc) and/or antibodies against hepatitis B surface antigen (anti-HBs) [6]. HBV reactivation in these patients used to occur mainly after hematopoietic stem cell transplantation or solid organ transplantation. However, after the approval of rituximab, HBV reactivation in non-Hodgkin lymphoma patients has increased. Rituximab is a humanized monoclonal antibody against CD20, which is expressed on the surface of B lymphocytes and is used to treat $\mathrm{B}$-cell non-Hodgkin lymphoma. Moreover, there have been subsequent reports of HBV reactivation in cases of immune-chemotherapy or immunosuppressive therapy for other malignancies or autoimmune disorders [7-10]. These patients included not only HBV carriers but 
also those with resolved HBV infection [11-13]. There have been several prospective studies on HBV reactivation among patients with malignant lymphoma in Asia [14-18]. The cumulative incidence rate of HBV reactivation in patients with resolved HBV infection who were treated with rituximab and steroid-containing regimens was reported to be $8.3 \%$ in a 1.5 -year study [18] and $41.5 \%$ in a 2-years study [17]. Of these, some patients developed HBV reactivation-related hepatitis and liver failure. Some risk factors and preventive strategies for HBV reactivation-related hepatitis have been reaching a consensus. Recently, HBV reactivation-related hepatitis and liver failure have been recognized as an important complication of cancer chemotherapy and immunosuppressive therapy.

Multiple myeloma (MM) is a neoplastic proliferation of plasma cells that are derived from B cells presenting various clinical conditions, such as anemia, renal dysfunction, osteolytic lesion, and hypercalcemia. Before the turn of the millennium, melphalan-prednisolone (MP) was the standard therapy for older patients, and high dose melphalan with autologous stem cell transplantation (ASCT) was the standard therapy for younger patients. However, the median overall survival (OS) was 38.9 months for the 1990-2000 cohort among Japanese MM patients [19], and accordingly, MM was recognized as a poor prognostic disease. After the turn of the millennium, the appearance of new treatment agents, including proteasome inhibitors, immunomodulatory drugs (IMiDs), and monoclonal antibodies, have significantly improved prognoses [20,21]. Among Japanese MM patients, the median OS was 60.6 months in the 2001-2012 cohort [19]. Before the use of these novel agents, HBV reactivation hardly occurred in patients who underwent ASCT. However, since then, cases of HBV reactivation have begun to be reported more commonly. Our previous retrospective study showed that HBV reactivation in MM patients was not rare and was significantly higher among patients who underwent ASCT than among those who did not undergo ASCT [22]. Therefore, we review HBV reactivation and its preventive strategy, based on a nationwide retrospective analysis and on other reports regarding MM patients.

\section{HBV Reactivation}

HBV has a very long-lasting form of the virus called covalently closed circular DNA (cccDNA). HBV persists in hepatocytes in patients with a history of transient HBV infection. Cellular and humoral immune responses commonly suppress viral replication. However, impairment of the host immune system due to chemotherapy or immunosuppressive therapy can result in active replication of HBV and a high viral load of HBV in the blood. Then immune reconstitution occurs, with $\mathrm{T}$ lymphocytes that recognize HBV attacking the liver, trying to clear HBV from the liver and leading to flares of hepatitis [23]. The incidence of HBV reactivation has been increasing since the approval of rituximab, suggesting that the function of B lymphocytes may well be more important. One of the functions of B lymphocytes is the production of neutralizing antibodies. It was reported that the presence of neutralizing antibodies contributes to HBV clearance [24]. They also speculated that B lymphocytes may have additional functions in suppressing HBV replication.

HBV reactivation was defined at a conference of the American Association for the Study of Liver Disease in 2013 [25]. The definition of HBV reactivation depends on the baseline virologic profile. $\mathrm{HBV}$ reactivation in HBV carriers is defined as a $\geq 2 \log _{10}$ increase in HBV DNA levels from baseline levels, the detection of HBV DNA with level $\geq 100 \mathrm{IU} / \mathrm{mL}$ in HBV carriers with undetectable HBV DNA at baseline, or the detection of HBV DNA with level $\geq 100,000 \mathrm{IU} / \mathrm{mL}$ in HBV carriers with no baseline HBV DNA data [25]. HBV reactivation in patients with resolved HBV infection is defined as the reappearance of HBsAg or the appearance of HBV DNA in the absence of HBsAg [25]. We classified the severity of HBV reactivation into five groups (Table 1) [24,26]. Although the vast majority of cases of HBV reactivation in MM patients correspond to virological changes that are not clinically significant, $\mathrm{HBV}$ reactivation can lead to death or necessitate the interruption of treatment. 
Table 1. Phases of HBV reactivation $[24,26]$.

\begin{tabular}{|c|c|}
\hline \multicolumn{2}{|l|}{ Virological Changes } \\
\hline HBsAg negative to $\mathrm{HBs} A g$ positive & $\begin{array}{l}\text { There is little clinical significance as it would not affect the } \\
\text { care of myeloma treatment. }\end{array}$ \\
\hline HBV DNA rising by 10 -fold & $\begin{array}{l}\text { Viral replication increases gradually. However, serum ALT } \\
\text { and AST levels are normal and patients are asymptomatic. } \\
\text { Increase in HBV DNA by 10-fold has little effect } \\
\text { on chemotherapy. }\end{array}$ \\
\hline \multicolumn{2}{|l|}{ Clinically significances } \\
\hline $\mathrm{HBV}$ reactivation with hepatitis & $\begin{array}{l}\text { ALT or AST levels become abnormal but not so high } \\
\text { ( } 2-10 \text { times the upper limit of normal or baseline levels). } \\
\text { This is important clinically as it might affect myeloma care. }\end{array}$ \\
\hline Severe hepatitis without liver failure & $\begin{array}{l}\text { ALT or AST levels become }>10 \text { times the upper limit } \\
\text { of normal or baseline levels. PT-INR remains normal. } \\
\text { This is important as it might lead to liver failure despite } \\
\text { treatment with HBV antiviral therapy. }\end{array}$ \\
\hline \multicolumn{2}{|l|}{ Fulminant hepatitis/death } \\
\hline Severe hepatitis leading to liver failure & $\begin{array}{l}\text { Liver failure is defined as (1) elevation in serum bilirubin } \\
\text { level }(>2 \mathrm{mg} / \mathrm{dL} \text { ) and prolongation of prothrombin time } \\
\text { (PT-INR }>1.3),(2) \text { ascites or ( } 3 \text { ) encephalopathy. This is } \\
\text { important as it can lead to death despite antiviral therapy. }\end{array}$ \\
\hline
\end{tabular}

The risk factors of HBV reactivation fall into three categories: (1) virological factors, (2) treatment factors, and (3) host factors [24]. First, the virological factors related to HBV reactivation include a high viral load at baseline, hepatitis B e antigen (HBeAg) positivity, and HBsAg positivity. A relationship between HBV genotype or mutations and HBV reactivation was reported recently [27]. Blood samples from 36 patients (17 with HBV reactivation and 19 with acute hepatitis) were analyzed using next-generation sequencing. The number of patients with genotype $B j$ was significantly higher in the HBV reactivation group than in the acute hepatitis group. The prevalence of the S3N amino acid substitution in the envelope protein, and G1896A and G1899A mutations in the pre-core region, was also significantly higher in the HBV reactivation group than in the acute hepatitis group.

HBV reactivation is affected by the virological state of HBV and the condition of the host's immune system. Patients with HBV infection may be classified into five phases: (1) immune-tolerant, (2) immune-active HBeAg-positive carrier, (3) inactive carrier, (4) HBeAg-negative chronic hepatitis, and (5) resolved infection [24,26,28-30]. This classification is based on patients' levels of alanine aminotransferase (ALT), HBV serological markers (HBsAg, anti-HBs, anti-HBc, HBeAg, antibodies against the hepatitis B e antigen [anti-HBe], and viral load). Immune-active HBeAg-positive carriers and patients with HBeAg-negative chronic hepatitis are characterized by high viral loads $(\geq 2000 \mathrm{IU} / \mathrm{mL})$, and ALT elevation [26,29]. An inactive carrier is also known as immune control and defined as testing positive for anti-HBe, having undetectable or low HBV DNA levels $(<2000 \mathrm{IU} / \mathrm{mL})$ and normal ALT levels [26,29]. Resolved infection is characterized by testing negative for $\mathrm{HBsAg}$ but positive for anti-HBc and/or anti-HBs with undetectable levels of HBV DNA [26,29]. The risk of HBV reactivation is higher for HBsAg-positive patients (immune-active HBeAg-positive carriers and patients with HBeAg-negative chronic hepatitis) than for HBsAg-negative patients (resolved infection). In a study of patients with B-cell non-Hodgkin lymphoma, the incidence rate for HBV reactivation in HBsAg-positive patients was higher than that in patients with resolved infection (20-50\% vs. $1.0-2.7 \%$ in patients on conventional chemotherapy, $>50 \%$ vs. $14-20 \%$ in patients who have had hematopoietic stem cell transplantation [HSCT], and $80 \%$ vs. $12.2-23.3 \%$ in patients on rituximab-containing regimens) [3]. Among HBsAg- 
positive patients, consultation with a hepatologist should be required to assist with decisions regarding the use of chemotherapy, immunosuppressive therapy, and antiviral therapy.

Second, the treatment factors can be divided into high risk, moderate risk, and low risk [30-32]. The several risk factors of treatment of HBV reactivation are solid organ or hematopoietic stem cell transplantation and the administration of rituximab, antitumor necrosis factor- $\alpha$ (TNF- $\alpha$ ) agents, steroids, and anthracycline [13,15,33-37]. The risk classification of treatments and drugs in MM is summarized in Table 2. Histone deacetylase inhibitors are classified into moderate risk groups [31,32]. However, we classified panobinostat usually combined with bortezomib for MM patients into the unclassifiable group, because there were no reports on panobinostat and HBV reactivation.

Table 2. Risk classifications of treatments and drugs resulting in multiple myeloma.

\begin{tabular}{cl}
\hline Risk and Prevalence of HBV Reactivation & \multicolumn{1}{c}{ Treatments and Drugs } \\
\hline High risk $(>10 \%)$ & $\begin{array}{l}\text { Hematopoietic stem cell transplantation } \\
\text { (autologous stem cell transplantation in almost cases) }\end{array}$ \\
\hline Moderate risk $(1-10 \%)$ & $\begin{array}{l}\text { Proteasome inhibitors, such as bortezomib } \\
\text { Anthracycline derivatives }\end{array}$ \\
& $\begin{array}{l}\text { Moderate (prednisolone } 10-20 \text { mg daily or equivalent) } \\
\text { or high-dose (prednisolone }>20 \text { mg daily or equivalent) } \\
\text { corticosteroids daily for }>4 \text { weeks }\end{array}$ \\
\hline Low risk $(<1 \%)$ & $\begin{array}{l}\text { IMiDs, such as thalidomide, lenalidomide and } \\
\text { pomalidomide } \\
\end{array}$ \\
& $\begin{array}{c}\text { Alkylating agents } \\
\text { Low-dose (prednisolone }<10 \text { mg or equivalent) } \\
\text { corticosteroids for }>4 \text { weeks } \\
\text { Any dose of oral corticosteroids daily for }<1 \text { week }\end{array}$ \\
\hline Unclassifiable & Monoclonal antibodies such as daratumumab \\
& and elotuzumab \\
& Histone deacetylase inhibitor, such as panobinostat * \\
\hline
\end{tabular}

\footnotetext{
* In some reviews, histone deacetylase inhibitors are classified into the moderate risk group. However, we classified panobinostat into the "unclassifiable group", because there are no reports that panobinostat induced HBV reactivation. Abbreviations: IMiDs, immunomodulatory drugs.
}

Third, the host factors, such as being male, being of older age, having elevated ALT levels, having hematopoietic malignancies, and having breast cancer, have also been reported [24,30,33,36-38].

A retrospective study by the Asian Lymphoma Study Group defined HBV reactivation as the reappearance of $\mathrm{HBsAg}$, in B-cell lymphoma patients who received rituximab-containing regimens [39]. In this study, HBV reactivation occurred in 19 of 261 patients, including four patients who died because of HBV reactivation-related hepatic failure despite the administration of antiviral agents (specifically, lamivudine [LAM] or entecavir [ETV]). In the process of HBV reactivation, a Chinese retrospective analysis presented crucial information that the median time from the elevation in serum HBV DNA levels to HBsAg seroreversion or hepatitis onset was 10 weeks (range, 8-12 weeks) and 18.5 weeks (range, 12-28 weeks), respectively [12]. Based on these facts, the diagnosis of HBV reactivation and administration of an antiviral agent need to be performed earlier than the reappearance of HBsAg.

HBV reactivation has been analyzed in four large-scale prospective studies of patients with malignant lymphoma and resolved HBV infection who received chemotherapy with or without rituximab [16-18,40] (Table 3). The Taiwan Cooperative Oncology Group conducted a prospective study of $150 \mathrm{HBsAg-negative} \mathrm{lymphoma} \mathrm{patients} \mathrm{receiving} \mathrm{rituximab-CHOP} \mathrm{(cyclophosphamide,}$ doxorubicin, vincristine, prednisolone)-based chemotherapy [16]. They defined HBV reactivation as HBV DNA levels $\geq 10$-fold above baseline levels and HBV reactivation-related hepatitis flares as a $\geq 3$-fold increase in serum ALT level that exceeded $100 \mathrm{IU} / \mathrm{L}$. They started ETV administration at the point of HBV reactivation. However, 17 of 150 patients experienced HBV reactivation, including 10 who 
developed HBV reactivation-related hepatitis flares. Thus, the study showed that the administration of antiviral agents at a point determined by HBV DNA levels might also be too late.

Table 3. Prospective studies on HBV reactivation in malignant lymphoma patients.

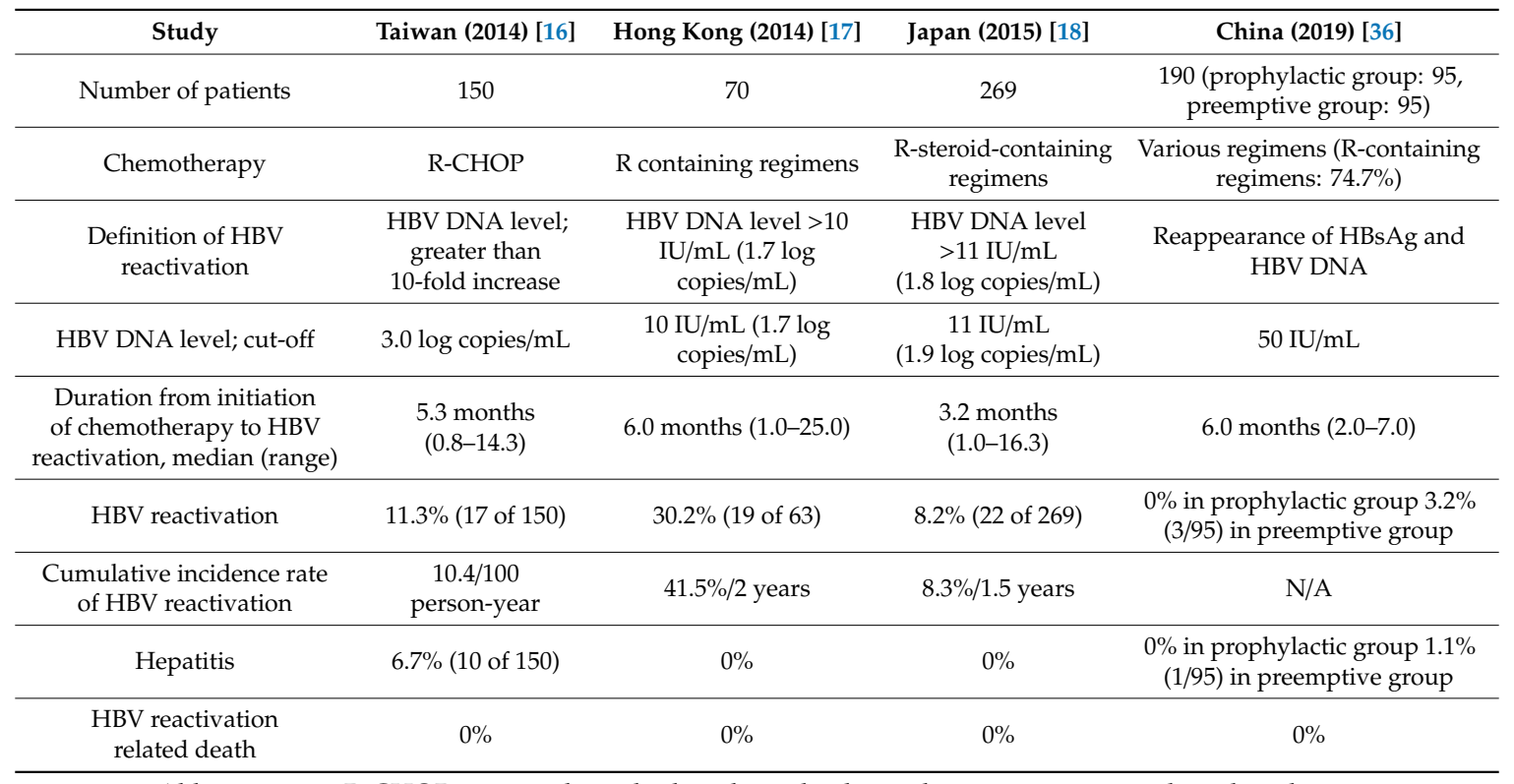

Abbreviations: R-CHOP, rituximab, cyclophosphamide, doxorubicin, vincristine and prednisolone.

A prospective study of B-cell non-Hodgkin lymphoma patients with resolved HBV infection treated with rituximab-containing regimens was performed in Hong Kong [17]. This study was conducted using a quantitative test for HBV DNA, in which a real-time polymerase chain reaction (RT-PCR) assay was performed every 4 weeks. Reactivation was determined to be the point at which any detectable levels of HBV DNA were found, and ETV was started at this point. In this study, HBV reactivation was observed in 19 of 63 cases $(30.2 \%)$, and none of the cases developed hepatitis.

A prospective study in Japan also reported a similar protocol for patients with B-cell non-Hodgkin lymphoma and resolved HBV infection who received chemotherapy including rituximab and steroids [18]. HBV reactivation was observed in 22 of 269 patients ( $8.2 \%)$, and none of these patients developed hepatitis. HBV DNA genotypes and mutations were evaluated in these 22 patients, and no patients with ETV resistance were observed. On the other hand, mutation of the pre-core region (G1896A), which is detected at a high rate in patients with fulminant hepatic failure, and mutation in the core promoter region (A1762T/G1764A), which is determined to accelerate virus growth radically, were observed in six cases, and HBV DNA levels increased more rapidly in these six patients than in others. However, in these patients, the onset of hepatitis could be prevented by ETV administration.

Recently, a Chinese group reported a prospective randomized controlled study for patients with malignant lymphoma and resolved HBV infection, to evaluate the efficacy and safety of ETV prophylaxis [40]. Patients were randomly assigned in a 1:1 ratio to either a prophylactic ETV group or a preemptive therapy group. HBV reactivation was defined as a reappearance of HBsAg and HBV DNA detection. In the prophylactic ETV group, antiviral administration was started from the initiation of chemotherapy to at least 6 months after the final dose of chemotherapy. In the preemptive therapy group, antiviral therapy was initiated as soon as patients were diagnosed as having HBV reactivation. The primary endpoints were the incidence rates of $\mathrm{HBV}$ reactivation and $\mathrm{HBV}$ reactivation-related hepatitis. The incidence rates of HBV reactivation and HBV reactivation-related hepatitis were $0 \%$ $(0 / 95)$ and $0 \%(0 / 95)$, respectively, in the prophylaxis group and 3.2\% (3/95) and 1.1\% (1/95), respectively, in the preemptive therapy group. There was no significant difference between the two therapy groups. One patient developed HBV reactivation-related hepatitis in the preemptive therapy group, but the 
authors did not discuss the reason for the onset of hepatitis. We thus deduced that the initiation of the antiviral agent at the time of HBsAg reappearance could be too late.

Based on these data, both routine monitoring of HBV DNA levels and starting administration of an antiviral agent at the point of detectable HBV DNA (preemptive therapy) have been recommended in some guidelines [41,42]. However, other guidelines and a recent review article stated that prophylactic administration of antiviral drugs is recommended for high-risk patients who receive regimens containing B-cell depleting agents or undergo HSCT [28,30,43-45].

Recent global studies have evaluated the incidence of HBV reactivation in B-cell non-Hodgkin lymphoma patients with resolved HBV infection who received immunochemotherapy containing B-cell depleting agents (obinutuzumab or rituximab) in phase III GOYA and GALLIUM studies [46]. Among 326 patients identified as being at high risk of HBV reactivation, $27(8.2 \%)$ experienced $\mathrm{HBV}$ reactivation. In the 232 patients without prophylactic nucleos(t)ide analog (NA) treatment, 25 (10.8\%) experienced HBV reactivation; these 25 patients received preemptive NA therapy, and none of them developed HBV reactivation-related hepatitis. In the 94 patients who received prophylactic NA treatment, two patients who received LAM (2.1\%) experienced HBV reactivation. Based on these studies $[17,18,46]$, we concluded that regular monitoring of HBV DNA and preemptive NA therapy is the most suitable for preventing HBV reactivation-related hepatitis among B-cell non-Hodgkin lymphoma patients.

\section{HBV Reactivation in MM Patients}

Retrospective reports summarizing HBV reactivation in MM patients, including case reports, included a total of 125 cases [8,22,47-68] (Tables 4 and 5). All 16 cases with HBV reactivation through 2010 underwent HSCT [56-61]. After 2010, the number of cases of HBV reactivation in patients receiving novel agents without HSCT increased. Only one case was reported after 2010 in which a patient received conventional MP therapy alone [8].

Table 4. HBV reactivation in MM patients (case reports).

\begin{tabular}{|c|c|c|c|c|c|c|c|}
\hline Reference & Age, Gender & MM Subtype & Treatment & Hepatitis & $\begin{array}{l}\text { Antiviral } \\
\text { Agents }\end{array}$ & $\begin{array}{c}\text { Time of Initiating } \\
\text { Antiviral } \\
\text { Therapy }\end{array}$ & Outcome \\
\hline $\begin{array}{c}\text { Tapan } \\
\text { (2011) [47] }\end{array}$ & 64 , male & $\mathrm{IgG}-\mathrm{K}$ & $\begin{array}{l}\text { RT, DEX, TD, } \\
\text { Bor with } \\
\text { tanespimycin, } \\
\text { Ld, CD, Benda } \\
\text { with DEX }\end{array}$ & $(+)$ & ETV & After hepatitis & $\begin{array}{l}\text { Died of fulminant } \\
\text { hepatic failure } \\
\text { after } 1 \text { month } \\
\text { of entecavir } \\
\text { treatment }\end{array}$ \\
\hline $\begin{array}{l}\text { Tanaka } \\
(2012)[48]\end{array}$ & 72 , male & IgG-K & MPT, BD & $(-)$ & ETV & $\begin{array}{c}\text { Preemptive } \\
\text { therapy }\end{array}$ & Alive with MM \\
\hline $\begin{array}{l}\text { Goldberg } \\
\text { (2013) [49] }\end{array}$ & 72 , male & N/A & Thal, Len, Bor & $(+)$ & ETV & After hepatitis & $\begin{array}{l}\text { Died of hepatic } \\
\text { failure }\end{array}$ \\
\hline $\begin{array}{l}\text { Hussain } \\
\text { (2014) [50] }\end{array}$ & 73 , female & N/A & $\begin{array}{c}\text { Vertebral } \\
\text { decompression, } \\
\text { RT, Bor and } \\
\text { liposomal } \\
\text { doxorubicin, } \\
\text { Len }\end{array}$ & $(-)$ & TDF & $\begin{array}{c}\text { Preemptive } \\
\text { therapy }\end{array}$ & Died of MM \\
\hline \multirow[t]{2}{*}{$\begin{array}{c}\text { Yang } \\
\text { (2014) [51] }\end{array}$} & 56 , male & IgG-K & $\begin{array}{c}\text { CDEP, CVAD, } \\
\text { Mel, ASCT, } \\
\text { VTD-PACE, } \\
\text { BLD }\end{array}$ & $(+)$ & TDF & After hepatitis & $\begin{array}{l}\text { Died of } \mathrm{PH} \text { and } \\
\text { bacteremia }\end{array}$ \\
\hline & 77 , male & IgG-K & $\begin{array}{l}\text { DT-PACE, } \\
\text { Mel, ASCT, } \\
\text { IFN }\end{array}$ & $(+)$ & $\begin{array}{c}\text { LAM } \rightarrow \\
\text { switched } \\
\text { to ETV }\end{array}$ & After hepatitis & $\begin{array}{l}\text { Alive with MM } \\
\text { (remission) }\end{array}$ \\
\hline $\begin{array}{l}\text { Silva-Pinto } \\
\text { (2015) [52] }\end{array}$ & 57 , male & $\operatorname{IgG}-\lambda$ & $\begin{array}{c}\text { TD, RT, ASCT, } \\
\text { BD, Thal } \\
\text { maintenance }\end{array}$ & N/A & $\begin{array}{l}\mathrm{ETV} \rightarrow \\
\text { added } \\
\text { to TDF }\end{array}$ & N/A & Died of MM \\
\hline $\begin{array}{c}\mathrm{Gu} \\
\text { (2015) [53] }\end{array}$ & 55 , male & IgG-K & $\begin{array}{c}\text { VAD, ASCT, } \\
\text { PSL } \\
\text { maintenance }\end{array}$ & $(+)$ & ETV & After hepatitis & Alive with MM \\
\hline
\end{tabular}


Table 4. Cont.

\begin{tabular}{ccccccc}
\hline Reference & Age, Gender & MM Subtype & Treatment & Hepatitis & $\begin{array}{c}\text { Antiviral } \\
\text { Agents }\end{array}$ & $\begin{array}{c}\text { Time of Initiating } \\
\text { Antiviral } \\
\text { Therapy }\end{array}$ \\
\hline $\begin{array}{c}\text { Danhof } \\
(2015)[54]\end{array}$ & 59, male & IgG-k & $\begin{array}{c}\text { VAD, tandem } \\
\text { ASCT, Bor, } \\
\text { Benda and Ld, } \\
\text { AUY-922 and } \\
\text { BD, BLCd, Pd }\end{array}$ & N/A & ETV & N/A \\
\hline $\begin{array}{c}\text { Almaghrabi } \\
(2017)[55]\end{array}$ & 68, male & N/A & $\begin{array}{c}\text { BCD, ASCT, } \\
\text { Len } \\
\text { maintenance }\end{array}$ & $(+)$ & ETV & After hepatitis \\
\hline
\end{tabular}

Abbreviations: ASCT, autologous stem cell transplantation; AUY-922, Hsp-90 inhibitor; BD, bortezomib and dexamethasone; $\mathrm{BCD}$, bortezomib, cyclophosphamide and dexamethasone; Benda, bendamustine; BLCd, bortezomib, lenalidomide, cyclophosphamide and dexamethasone; BLD, bortezomib, lenalidomide, and dexamethasone; Bor, bortezomib; CD, cyclophosphamide and dexamethasone; CDEP, cyclophosphamide, dexamethasone, etoposide, and cisplatin; CVAD, cyclophosphamide, vincristine, doxorubicin, and prednisolone; DEX, dexamethasone; DT-PACE, dexamethasone, thalidomide, cisplatin, doxorubicin, cyclophosphamide, and etoposide; ETV, entecavir; IFN, interferon; LAM, lamivudine, Ld, lenalidomide and dexamethasone; Len, lenalidomide; Mel, melphalan; MM, multiple myeloma; MPT, melphalan, prednisolone, and thalidomide; $\mathrm{Pd}$, pomalidomide and dexamethasone; $\mathrm{PH}$, pulmonary hypertension; RT, radiotherapy; TD, thalidomide and dexamethasone; TDF, tenofovir; Thal, thalidomide; VAD, vincristine, doxorubicin, and dexamethasone; VTD-PACE, bortezomib, thalidomide, dexamethasone, cisplatin, doxorubicin, cyclophosphamide, and etoposide.

Table 5. HBV reactivation in MM patients (case series).

\begin{tabular}{|c|c|c|c|c|c|c|c|}
\hline Reference & $\begin{array}{c}\text { Number } \\
\text { of Patients } \\
\text { (MM Patients) }\end{array}$ & $\begin{array}{c}\text { Number } \\
\text { of Patients } \\
\text { with HBV } \\
\text { Reactivation } \\
\text { (MM Patients) }\end{array}$ & $\begin{array}{c}\text { Definition } \\
\text { of HBV } \\
\text { Reactivation }\end{array}$ & $\begin{array}{c}\text { Number } \\
\text { of Patients Who } \\
\text { Developed } \\
\text { Hepatitis } \\
\text { (MM Cases) }\end{array}$ & $\begin{array}{c}\text { Antiviral } \\
\text { Agents }\end{array}$ & $\begin{array}{c}\text { Number } \\
\text { of Patients } \\
\text { Who Died } \\
\text { of Hepatitis } \\
\text { (MM Patients) }\end{array}$ & Risk Factors \\
\hline $\begin{array}{c}\text { Endo } \\
\text { (2000) [56] }\end{array}$ & 47 (13) & $3(3)$ & $\begin{array}{l}\text { Reappearance } \\
\text { of HBsAg }\end{array}$ & $3(3)$ & $\begin{array}{l}\text { Not } \\
\text { received }\end{array}$ & 0 & Steroid \\
\hline $\begin{array}{c}\text { Uhm } \\
\text { (2007) [57] }\end{array}$ & $141(53)$ & $7(6)$ & $\begin{array}{l}\text { Reappearance } \\
\text { of HBsAg }\end{array}$ & 5 (N/A) & LAM & 0 & N/A \\
\hline $\begin{array}{c}\text { Matsue } \\
\text { (2009) [58] }\end{array}$ & $81(12)$ & $6(1)$ & $\begin{array}{l}\text { Reappearance } \\
\text { of HBsAg }\end{array}$ & $4(0)$ & LAM, ETV & 0 & N/A \\
\hline $\begin{array}{c}\text { Ceneli } \\
\text { (2010) [59] }\end{array}$ & $90(46)$ & $3(3)$ & $\begin{array}{c}\text { Reappearance } \\
\text { of HBsAg with } \\
\text { increase in HBV } \\
\text { DNA level }\end{array}$ & $3(3)$ & LAM & 0 & N/A \\
\hline $\begin{array}{l}\text { Yoshida } \\
\text { (2010) [60] }\end{array}$ & $15(15)$ & $2(2)$ & $\begin{array}{l}\text { HBV DNA level } \\
\text { becomes } \\
\text { detectable }\end{array}$ & $1(1)$ & ETV & 0 & N/A \\
\hline $\begin{array}{c}\text { Borentain } \\
\text { (2010) [61] }\end{array}$ & 84 (N/A) & $7(1)$ & $\begin{array}{c}\text { HBV DNA level } \\
\text { becomes } \\
\text { detectable }\end{array}$ & $7(1)$ & LAM & $3(1)$ & $\begin{array}{l}>1 \text { line } \\
\text { of chemotherapy }\end{array}$ \\
\hline $\begin{array}{c}\text { Lee (2015) } \\
\text { [62] }\end{array}$ & $230(230)$ & $12(12)$ & $\begin{array}{l}\text { Reappearance } \\
\text { of HBsAg }\end{array}$ & 8 & $\begin{array}{l}\text { LAM, ETV, } \\
\text { TDF }\end{array}$ & 0 & $\begin{array}{c}\text { ASCT, } \\
\text { anti-HBs } \\
\text { negative }\end{array}$ \\
\hline $\begin{array}{c}\operatorname{Li}(2015) \\
{[63]}\end{array}$ & $112(112)$ & $2(2)$ & $\begin{array}{l}\text { Loss of anti-HBs } \\
\text { and reappearance } \\
\text { of HBsAg Increase } \\
\text { of HBV DNA level }\end{array}$ & N/A & LAM, ETV & 0 & N/A \\
\hline $\begin{array}{l}\text { Takahashi } \\
\text { (2015) [8] }\end{array}$ & N/A & $11(4)$ & $\begin{array}{c}\text { Reappearance } \\
\text { of HBsAg or }> \\
10 \text {-fold increase } \\
\text { in HBV DNA or } \\
\text { HBV-DNA level } \\
\text { becomes } \\
\text { detectable }\end{array}$ & $4(2)$ & LAM, ETV & $4(1)$ & N/A \\
\hline $\begin{array}{l}\text { Tsukune } \\
\text { (2016) [64] }\end{array}$ & 99 (99) & $9(9)$ & $\begin{array}{c}\text { HBV DNA level } \\
\text { becomes } \\
\text { detectable }\end{array}$ & 0 & ETV & 0 & $\begin{array}{l}\text { elevated } \\
\text { serum } \\
\text { albumin }\end{array}$ \\
\hline $\begin{array}{l}\text { Mochida } \\
\text { (2016) [65] }\end{array}$ & 289 (N/A) & $20(2)$ & $\begin{array}{l}\text { HBV DNA level } \\
\text { becomes } \\
\text { detectable }\end{array}$ & N/A & ETV & N/A & N/A \\
\hline
\end{tabular}


Table 5. Cont.

\begin{tabular}{|c|c|c|c|c|c|c|c|}
\hline Reference & $\begin{array}{c}\text { Number } \\
\text { of Patients } \\
\text { (MM Patients) }\end{array}$ & $\begin{array}{c}\text { Number } \\
\text { of Patients } \\
\text { with HBV } \\
\text { Reactivation } \\
\text { (MM Patients) }\end{array}$ & $\begin{array}{c}\text { Definition } \\
\text { of HBV } \\
\text { Reactivation }\end{array}$ & $\begin{array}{c}\text { Number } \\
\text { of Patients Who } \\
\text { Developed } \\
\text { Hepatitis } \\
\text { (MM Cases) }\end{array}$ & $\begin{array}{c}\text { Antiviral } \\
\text { Agents }\end{array}$ & $\begin{array}{c}\text { Number } \\
\text { of Patients } \\
\text { Who Died } \\
\text { of Hepatitis } \\
\text { (MM Patients) }\end{array}$ & Risk Factors \\
\hline $\begin{array}{c}\text { Han (2016) } \\
{[66]}\end{array}$ & 738 (54) & $23(6)$ & $\begin{array}{l}\text { Reappearance } \\
\text { of HBsAg }\end{array}$ & N/A & $\begin{array}{l}\text { ETV, TDF, } \\
\text { LdT }\end{array}$ & $1(0)$ & $\begin{array}{c}\text { loss } \\
\text { of anti-HBs, } \\
\text { ALL, MM }\end{array}$ \\
\hline $\begin{array}{c}\text { Varma } \\
\text { (2017) [67] }\end{array}$ & 107 (107) & $7(7)$ & $\begin{array}{l}\text { Reappearance } \\
\text { of HBsAgor > } \\
\text { 10-fold increase } \\
\text { in HBV DNA }\end{array}$ & N/A & LAM, TDF & 0 & N/A \\
\hline $\begin{array}{l}\text { Tsukune } \\
\text { (2017) [22] }\end{array}$ & $760(760)$ & $58(58)$ & $\begin{array}{l}\text { HBV DNA level } \\
\text { becomes } \\
\text { detectable }\end{array}$ & 10 & LAM, ETV & 1 & $\begin{array}{c}\text { ASCT, } \\
\text { lenalidomide * }\end{array}$ \\
\hline $\begin{array}{c}\text { Ataca } \\
\text { Atilla P } \\
(2019)[68]\end{array}$ & $178(178)$ & $8(8)$ & $\begin{array}{l}\text { Loss of anti-HBs } \\
\text { and reappearance } \\
\text { of HBsAg Increase } \\
\text { of HBV DNA level }\end{array}$ & N/A & LAM, TDF & N/A & N/A \\
\hline
\end{tabular}

* Lenalidomide significantly reduced risk of HBV reactivation. Abbreviations: ALL, acute lymphoblastic leukemia; anti-HBs, antibodies against hepatitis B surface antigen; ASCT, autologous stem cell transplantation; ETV, entecavir; LAM, lamivudine, LdT, telbivudine; MM, multiple myeloma; TDF, tenofovir.

HBV reactivation has been reported in two relatively large-scale retrospective studies of patients with MM and resolved HBV infection from Korea and Japan [22,62]. A Korean study reported about $628 \mathrm{MM}$ cases in a single institution [62], and the researchers defined HBV reactivation as the reappearance of HBsAg and analyzed 230 cases (36.6\%) with resolved HBV infection. During a median follow-up period of 2.4 years, HBV reactivation was observed in 12 cases (5.2\%). The cumulative incidence rate of $\mathrm{HBV}$ reactivation at 2 and 5 years was $5 \%$ and $8 \%$, respectively. ASCT was performed in 127 patients, including all 12 with HBV reactivation. The researchers revealed that ASCT and anti-HBs negativity were risk factors for HBV reactivation. In addition, the researchers defined biochemical flare as the elevation in serum ALT levels $(\geq 80 \mathrm{U} / \mathrm{L})$, which was observed in eight of the 12 patients.

Our first study reported that, among 641 Japanese MM patients, one of eight (12.5\%) HBV carriers developed hepatitis, and nine of $99(9.1 \%)$ patients with resolved HBV infection experienced HBV reactivation [64]. Furthermore, the cumulative incidences of HBV reactivation at 2 and 5 years were $8 \%$ and $14 \%$, respectively. Univariate analysis identified elevated serum albumin level as the only risk factor for HBV reactivation. This association could not be reasonably explained. We concluded that $\mathrm{HBV}$ reactivation was not rare, although risk factors and optimal preventive strategies for HBV reactivation were not identified. Therefore, we conducted a nationwide retrospective study aimed at evaluating the actual incidence and risk factors of $\mathrm{HBV}$ reactivation.

Our Japanese nationwide study collected data of 5,078 MM patients from 76 Japanese hospitals [22]. All patients were either treated with novel agents (bortezomib, thalidomide, lenalidomide, pomalidomide, panobinostat, carfilzomib, elotuzumab, and ixazomib) or underwent ASCT. Of these patients, $760(15.0 \%)$ exhibited resolved HBV infection. HBV reactivation was defined as the detection of HBV DNA in the peripheral blood during or after treatment. During the median follow-up period of 101 (1-540) weeks, HBV reactivation was observed in 58 cases $(7.6 \%)$. The cumulative incidence rates of HBV reactivation at 2 and 5 years were $7.9 \%$ and $14.1 \%$, respectively. The cumulative incidence of HBV reactivation was higher in patients who underwent ASCT $(16.0 \%$ at 2 years; $30.6 \%$ at 5 years) than in those who did not (4.4\% at 2 years; $4.8 \%$ at 5 years). Ten of 58 patients $(17.2 \%)$ with HBV reactivation developed hepatitis, and one of these patients died of fulminant hepatitis despite the administration of the antiviral agent. These 10 patients were not regularly monitored for HBV DNA levels; instead, HBV reactivation was diagnosed after an elevation in ALT levels was observed. The other 48 patients were subjected to regular HBV DNA monitoring and preemptive antiviral therapy as per Japanese guidelines [23], and none developed HBV-reactivation-related hepatitis. In the univariate analysis, a high incidence of $\mathrm{HBV}$ reactivation was observed in groups 
with elevated serum albumin levels, of younger age, with decreased gamma-glutamyl transpeptidase levels, and that underwent ASCT. Multivariate analysis revealed that ASCT was a strong risk factor of $\mathrm{HBV}$ reactivation. In contrast, lenalidomide treatment was associated with a low prevalence of $\mathrm{HBV}$ reactivation.

Thus, we identified a general trend in these Korean and Japanese studies showing that HBV reactivation is not rare among MM patients, especially among patients who underwent ASCT.

\section{The Prophylactic Strategy for HBV Reactivation in MM Patients}

There are no prospective studies or established guidelines on HBV reactivation in MM patients. In the previously described two retrospective studies among MM patients, the cumulative incidence rate of HBV reactivation was higher and the rate of biochemical flare was lower in the Japanese study than in the Korean study [22,62]. The difference in these rates may be attributed to the different definitions used for HBV reactivation in each study. Similarly, from the reports on malignant lymphoma, we identified that a diagnosis of $\mathrm{HBV}$ reactivation at the point of HBsAg seroconversion was too late for the prevention of HBV reactivation-related hepatitis. Meanwhile, the prospective study of Japanese patients with malignant lymphoma showed that management including regular HBV DNA monitoring and/or preemptive antiviral therapy was practical [18], and none of the patients in our study who were treated in the same way developed either HBV reactivation-related hepatitis or liver failure [22]. We suggest that this strategy of HBV DNA monitoring and preemptive therapy is the most reasonable and practical considering the present understanding and analytical capabilities.

The antiviral agents LAM and ETV have been widely used for the prevention of HBV reactivation-related hepatitis. Among patients with B-cell non-Hodgkin lymphoma and HBV carriers, a randomized controlled study showed a significantly lower incidence of HBV reactivation and HBV reactivation-related hepatitis in the study's ETV prophylactic group than in its LAM prophylactic group [69]. The authors suggested that the reason for the better outcome of ETV prophylactic group was that ETV had potent antiviral activity and a high genetic barrier to resistance. Other studies showed that long-term administration of LAM was significantly associated with drug resistance [46,70,71]. ETV was used to address HBV reactivation in a Japanese prospective study of malignant lymphoma, in which there were no cases that showed resistance to ETV [18]. The duration of treatment in MM patients is usually longer than that in lymphoma patients. Therefore, although we currently recommend ETV for the prophylaxis of HBV reactivation-related hepatitis, we also propose that a consultation with a hepatologist should be required at the time of HBV reactivation.

Some recent guidelines recommend other NAs, such as tenofovir disoproxil fumarate (TDF) and tenofovir alafenamide (TAF), for the prevention of HBV reactivation [28,72]. In recent studies, TDF completely prevented the onset of $\mathrm{HBV}$ reactivation and the development of HBV reactivation-related hepatitis in malignant lymphoma patients [73,74]. In addition, TDF has no reported occurrences of resistant mutation after 6 years of treatment [75].

However, it is necessary to pay attention to the administration of NAs because renal dysfunction and reduction in bone mineral density are known to be adverse effects of these agents and because the effects correspond to organ damage caused by MM [76,77]. It was reported that less than $1 \%$ of patients treated with ETV had elevated serum creatinine [78]. TDF may result in mild proximal tubular dysfunction, and renal toxicity tends to increase with cumulative exposure. There was a report on the 7-year efficacy and safety of TDF treatment in 585 chronic hepatitis B patients, of whom only $10(1.7 \%)$ experienced elevation in serum creatinine levels $\geq 0.5 \mathrm{mg} / \mathrm{dL}$ at baseline [79]. Compared with TDF, TAF is said to cause less renal toxicity. However, ETV and TDF require dose adjustments based on creatinine clearance values. Thus, we need to carefully observe renal function when ETV and TDF are used for MM patients. Bone events following NA treatment did not increase significantly, except for hip fracture in a large cohort study [80]. However, MM patients with osteolytic lesions or bone plasmacytoma need to be closely monitored by means of bone density testing. 
In malignant lymphoma studies, the median duration from the initiation of chemotherapy to the occurrence of HBV reactivation was less than 6 months [16-18] (Table 2). The late onset of HBV reactivation ("late" being defined as occurring between 6 and 12 months after completion of therapy) for rituximab-containing immunochemotherapy rarely occurs in B-cell non-Hodgkin lymphoma patients [46,81,82]. Conversely, 38 patients who underwent ASCT experienced HBV reactivation (median, 55 weeks; range, 10-250 weeks), and six patients of those had HBV reactivation more than 2 years after transplantation in our study [22]. Most of these patients were receiving chemotherapy owing to the recurrence of MM. However, one case developed HBV reactivation after ASCT despite complete remission and more than 4 years after cessation of chemotherapy. Moreover, in our study, while most of the 20 cases of HBV reactivation without ASCT occurred within 2 years since treatment initiation, one of them occurred after more than 6 years. Unlike malignant lymphoma, most MM patients receive treatment for a long time because $\mathrm{MM}$ is an incurable disease. A new strategy, with maintenance therapy and salvage therapy including novel agents, has been improving the prognosis of MM patients $[83,84]$. Consequentially, the use of novel agents has led to a more prolonged term treatment for MM patients. The regular monitoring of HBV DNA is necessary for at least 12 months after treatment completion in Japanese guidelines [23]. However, late HBV reactivation has occurred more frequently in MM patients than in lymphoma patients, as previously demonstrated by the over 6 year interval before reactivation was observed in our patient. HBV DNA monitoring for MM patients, especially those who underwent ASCT, should probably be required for quite a longer time and more carefully than that for lymphoma patients, even after treatment is discontinued.

According to the Japanese guidelines, cessation of antiviral therapy can be considered if the following three criteria are met: (1) antiviral therapy has been continued for at least 12 months after the completion of chemotherapy or immunosuppressive therapy; (2) ALT levels have been normalized during this period (except, for example, cases with fatty liver and drug-induced liver dysfunction); and (3) HBV DNA levels are continuously below detectable limits during this period (and, ideally, HBsAg and hepatitis B core-related antigens are also continuously negative) [23]. Both a recent Australian consensus statement and other guidelines recommend that patients with resolved HBV infection who previously received B-cell-depleting agents or underwent HSCT require prophylactic NA therapy for 12-24 months after treatment completion and continued HBV DNA monitoring for at least 12 months after prophylaxis withdrawal $[28,45,85]$. The same consensus statement recommended that patients with other chemotherapies continue prophylactic NA therapy for 6-12 months. However, this statement is not enough for MM patients. The optimal period of prophylactic NA therapy for MM patients may need longer durations.

The main merit of preemptive therapy is the avoidance of unnecessary administration of antiviral agents. In our study, only $5 \%$ of patients who were ineligible for transplantation needed antiviral therapy [22]. Antiviral agents may be used as prophylaxis in patients who do not require antiviral therapy. In the previously described Chinese study [40], the incidence rates of HBV reactivation and HBV reactivation-related hepatitis in the prophylactic antiviral therapy group were not significantly higher than those in the preemptive therapy group. This study also assessed cost-effectiveness. The base-case annual costs were $\$ 2,536$ per patient in the prophylactic ETV group and $\$ 1,039$ in the control group. The cost of the prophylactic ETV group was higher than that in the control group (\$125 per month per patient). Continuous prophylaxis using antivirals during and after chemotherapy for MM is not economical, because the duration of treatment is usually longer in MM patients than in lymphoma patients. The main drawback of preemptive therapy is that patients may develop severe hepatitis owing to a delay in the diagnosis of HBV reactivation. HBV reactivation may not be detected in a timely fashion in routine practice rather than in the setting of a clinical trial. In fact, 10 patients received a delayed diagnosis of $\mathrm{HBV}$ reactivation and experienced hepatitis in our study. Moreover, HBV DNA testing is very expensive, and it takes a long time to obtain the result in some regions.

On the other hand, the advantage of prophylactic therapy is the suppression of HBV replication and the decrease in the incidence rate of $\mathrm{HBV}$ reactivation. The disadvantages of prophylactic therapy 
are the appearance of resistant mutations and adverse events caused by antiviral agents. Further research is needed on how to resolve these clinical issues.

In resource-limited settings, access to diagnostic tests and the availability of treatment are limited and are not affordable. In these countries, a specialized strategy to manage HBV reactivation in MM patients is needed.

\section{Effect of Novel Agents on HBV Reactivation}

The effects of bortezomib include the suppression of $\mathrm{T}$ lymphocyte proliferation and a decrease and hypofunction of both natural killer cells and CD8-positive T cells [86]. Treatment with bortezomib may be a major risk factor for the reactivation of herpes simplex virus and varicella-zoster virus (VZV), and thus, the prophylactic coadministration of antiviral agents against VZV is recommended [86]. Similarly, bortezomib might also be considered a possible risk factor for HBV reactivation. A recent report revealed that c-Abl, which regulates cell growth and survival, promotes cellin-RING ligase 4 mediated ubiquitination of HBV polymerase and further suppresses HBV replication [87]. Bortezomib blocks the ubiquitination of HBV polymerase by inhibiting c-Abl kinase activity in vitro and in vivo, and this mechanism may contribute to increasing cases with HBV reactivation.

The first HBV reactivation case treated with bortezomib was reported in Japan [48], and reports on $\mathrm{HBV}$ reactivation cases associated with bortezomib have subsequently increased. Li et al. retrospectively reported about 139 Chinese MM patients who underwent bortezomib-containing chemotherapy [63]. In this report, $\mathrm{HBV}$ reactivation occurred in $7.7 \%$ of patients who were $\mathrm{HBV}$ carriers and who were treated with bortezomib-containing therapy and in $1.3 \%$ of patients treated with conventional chemotherapy, without ASCT and novel agents. One case with resolved HBV infection experienced $\mathrm{HBV}$ reactivation during chemotherapy including bortezomib. Meanwhile, some patients who received carfilzomib-containing regimens also experienced HBV reactivation [68]. HBV reactivation owing to ixazomib has not been reported as of now. Proteasome inhibitors have been recognized as a risk factor of $\mathrm{HBV}$ reactivation [31].

There have only been a few reports on the incidence of HBV reactivation among MM patients who were treated with lenalidomide- or pomalidomide-based regimens $[54,88]$. Our nationwide study revealed that lenalidomide significantly reduced HBV reactivation [22]. Of 58 patients who exhibited HBV reactivation, only one patient did not undergo ASCT and was not administered the novel agents without lenalidomide.

Lenalidomide is classified as an IMiD that targets cereblon (CRBN) to induce antitumor activity and immunomodulatory effects through the proliferation of immune effector cells such as $\mathrm{T}$ cells, natural killer cells, and dendritic cells. In the RNA-induced silencing complex, the argonaute 2 (AGO2) protein is the only member with catalytic activity and fulfills a central role, thereby regulating small-RNA-guided gene-splicing processes [89]. Xu et al. showed that AGO2 bound to CRBN and was negatively regulated by CRBN in MM cells [90]. In this study, lenalidomide significantly increased the expression of CRBN in myeloma cell lines. Conversely, lenalidomide decreased the levels of AGO2 and microRNAs. It was demonstrated that knocking down AGO2 induced a decrease in the levels of HBsAg and HBV DNA in cell lines transfected with a plasmid of HBV components [91]. Altogether, we speculated at the time that lenalidomide might inhibit HBV proliferation by decreasing AGO2 levels in MM patients [22]. Recently, The other group revealed that lenalidomide significantly enhanced interferon- $\alpha$ production by human plasmacytoid dendritic cells [92]. Interferon- $\alpha$ (currently pegylated interferon- $\alpha$ ) is one of the main treatment options for active HBV hepatitis patients. This result suggests that immunomodulatory effects owing to lenalidomide may inhibit HBV proliferation in MM patients.

In addition, we can use monoclonal antibodies (e.g., elotuzumab and daratumumab) for MM patients. Currently, there are no reports on HBV reactivation owing to monoclonal antibodies. The European Society of Clinical Microbiology and Infectious Diseases Study Group for Infections in Compromised Hosts recently reported that daratumumab (with corticosteroid) might increase the incidence of HBV reactivation [93]; however, the mechanism for this is unknown. What is known is 
that daratumumab depletes CD38 positive regulatory $\mathrm{T}$ and $\mathrm{B}$ cells and myeloid-derived suppressor cells and increases cytotoxic $\mathrm{T}$ cell number and activation [94]. These cytotoxic $\mathrm{T}$ cells may attack HBV-infected hepatocytes, leading to HBV reactivation-related hepatitis.

\section{Conclusions}

A recent Japanese nationwide study revealed that among 31 patients with resolved HBV infection who developed HBV reactivation-related acute liver failure or late-onset hepatic failure owing to chemotherapy and/or immunosuppressive therapy between 2010 and 2015, 27 (87.1\%) patients died [95]. HBV reactivation can lead to fatal fulminant hepatitis, and the incidence rate of HBV reactivation in $\mathrm{MM}$ patients has been increasing.

In our study, no patients who were subjected to regular HBV DNA monitoring and preemptive antiviral therapy as per Japanese guidelines developed HBV reactivation-related hepatitis. We conclude that regular monitoring of HBV DNA and preemptive NA therapy is the most reasonable and practical for preventing HBV reactivation-related hepatitis among MM patients. However, the development of novel agents has dramatically improved the prognosis for MM. It is necessary to be aware that $\mathrm{HBV}$ reactivation can occur at any treatment phase and that regular monitoring of HBV DNA levels is required on a long-term basis. In addition, there remain some unresolved clinical variables regarding HBV reactivation in MM patients, such as the administration period for antiviral agents and the appropriate methods for HBV monitoring. Further large-scale prospective studies should aim to identify risk factors associated with novel agents more clearly and establish a new strategy to prevent HBV reactivation in MM patients.

Author Contributions: Drafting of the manuscript, Y.T.; critical revision of the manuscript, M.S. and N.K.

Funding: This research received no external funding.

Conflicts of Interest: The authors have no conflict of interests related to this publication.

\section{References}

1. Ocama, P.; Opio, C.K.; Lee, W.M. Hepatitis B virus infection: Current status. Am. J. Med. 2005, 118, 1413. [CrossRef]

2. World Health Organization. Hepatitis: Fact Sheet. July 2019. Available online: https://www.who.int/en/ news-room/factsheets/detail/hepatitis-b (accessed on 9 September 2019).

3. Kusumoto, S.; Tanaka, Y.; Ueda, R.; Mizokami, M. Reactivation of hepatitis B virus following rituximab-plus-steroid combination chemotherapy. J. Gastroenterol. 2011, 46, 9-16. [CrossRef]

4. Yeo, W.; Chan, P.K.; Ho, W.M.; Zee, B.; Lam, K.C.; Lei, K.I.; Chan, A.T.; Mok, T.S.; Lee, J.J.; Leung, T.W.; et al. Lamivudine for the prevention of hepatitis B virus reactivation in hepatitis B s-antigen seropositive cancer patients undergoing cytotoxic chemotherapy. J. Clin. Oncol. 2004, 22, 927-934. [CrossRef] [PubMed]

5. Lau, G.K.; Yiu, H.H.; Fong, D.Y.; Cheng, H.C.; Au, W.Y.; Lai, L.S.; Cheung, M.; Zhang, H.Y.; Lie, A.; Ngan, R.; et al. Early is superior to deferred preemptive lamivudine therapy for hepatitis B patients undergoing chemotherapy. Gastroenterology 2003, 125, 1742-1749. [CrossRef] [PubMed]

6. Wands, J.R.; Chura, C.M.; Roll, F.J.; Maddrey, W.C. Serial studies of hepatitis-associated antigen and antibody in patients receiving antitumor chemotherapy for myeloproliferative and lymphoproliferative disorders. Gastroenterology 1975, 68, 105-112. [PubMed]

7. Calabrese, L.H.; Zein, N.N.; Vassilopoulos, D. Hepatitis B virus (HBV) reactivation with immunosuppressive therapy in rheumatic diseases: Assessment and preventive strategies. Ann. Rheum. Dis. 2006, 65, 983-989. [CrossRef]

8. Takahashi, H.; Ikeda, M.; Kumada, T.; Osaki, Y.; Kondo, S.; Kusumoto, S.; Ohkawa, K.; Nadano, S.; Furuse, J.; Kudo, M.; et al. Multicenter cooperative case survey of hepatitis B virus reactivation by chemotherapeutic agents. Hepatol. Res. 2015, 45, 1220-1227. [CrossRef]

9. Voican, C.S.; Mir, O.; Loulergue, P.; Dhooge, M.; Brezault, C.; Dreanic, J.; Chaussade, S.; Pol, S.; Coriat, R. Hepatitis $\mathrm{B}$ virus reactivation in patients with solid tumors receiving systemic anticancer treatment. Ann. Oncol. 2016, 27, 2172-2184. [CrossRef] 
10. Fukuda, W.; Hanyu, T.; Katayama, M.; Mizuki, S.; Okada, A.; Miyata, M.; Handa, Y.; Hayashi, M.; Koyama, Y.; Arii, K.; et al. Incidence of hepatitis B virus reactivation in patients with resolved infection on immunosuppressive therapy for rheumatic disease: A multicentre, prospective, observational study in Japan. Ann. Rheum. Dis. 2017, 76, 1051-1056. [CrossRef]

11. Dervite, I.; Hober, D.; Morel, P. Acute hepatitis B in a patient with antibodies to hepatitis B surface antigen who was receiving rituximab. N. Engl. J. Med. 2001, 344, 68-69. [CrossRef]

12. Hui, C.K.; Cheung, W.W.; Zhang, H.Y.; Au, W.Y.; Yueng, Y.H.; Leung, A.Y.; Leung, N.; Luk, J.M.; Lie, A.K.; Kwong, Y.L.; et al. Kinetics and risk of de novo hepatitis B infection in HBsAg-negative patients undergoing cytotoxic chemotherapy. Gastroenterology 2006, 131, 59-68. [CrossRef] [PubMed]

13. Yeo, W.; Chan, T.C.; Leung, N.W.; Lam, W.Y.; Mo, F.K.; Chu, M.T.; Chan, H.L.; Hui, E.P.; Lei, K.I.; Mok, T.S.; et al. Hepatitis B virus reactivation in lymphoma patients with prior resolved hepatitis B undergoing anticancer therapy with or without rituximab. J. Clin. Oncol. 2009, 27, 605-611. [CrossRef] [PubMed]

14. Hui, C.K.; Sun, J.; Au, W.Y.; Lie, A.K.; Yueng, Y.H.; Zhang, H.Y.; Lee, N.P.; Hou, J.L.; Liang, R.; Lau, G.K. Occult hepatitis B virus infection in hematopoietic stem cell donors in a hepatitis B virus endemic area. J. Hepatol. 2005, 42, 813-819. [CrossRef] [PubMed]

15. Kusumoto, S.; Tanaka, Y.; Mizokami, M.; Ueda, R. Reactivation of hepatitis B virus following systemic chemotherapy for malignant lymphoma. Int. J. Hematol. 2009, 90, 13-23. [CrossRef]

16. Hsu, C.; Tsou, H.H.; Lin, S.J.; Wang, M.C.; Yao, M.; Hwang, W.L.; Kao, W.Y.; Chiu, C.F.; Lin, S.F.; Lin, J.; et al. Taiwan Cooperative Oncology Group Chemotherapy-induced hepatitis B reactivation in lymphoma patients with resolved HBV infection: A prospective study. Hepatology 2014, 59, 2092-2100. [CrossRef]

17. Seto, W.K.; Chan, T.S.; Hwang, Y.Y.; Wong, D.K.; Fung, J.; Liu, K.S.; Gill, H.; Lam, Y.F.; Lie, A.K.; Lai, C.L.; et al. Hepatitis $B$ reactivation in patients with previous hepatitis B virus exposure undergoing rituximab-containing chemotherapy for lymphoma: A prospective study. J. Clin. Oncol. 2014, 32, 3736-3743. [CrossRef]

18. Kusumoto, S.; Tanaka, Y.; Suzuki, R.; Watanabe, T.; Nakata, M.; Takasaki, H.; Fukushima, N.; Fukushima, T.; Moriuchi, Y.; Itoh, K.; et al. Monitoring of hepatitis B virus (HBV) DNA and risk of HBV reactivation in B-cell lymphoma: A prospective observational study. Clin. Infect. Dis. 2015, 61, 719-729. [CrossRef]

19. Ozaki, S.; Handa, H.; Saitoh, T.; Murakami, H.; Itagaki, M.; Asaoku, H.; Suzuki, K.; Isoda, A.; Matsumoto, M.; Sawamura, M.; et al. Trends of survival in patients with multiple myeloma in Japan: A multicenter retrospective collaborative study of the Japanese Society of Myeloma. Blood Cancer J. 2015, 5, e349. [CrossRef]

20. Kumar, S.K.; Rajkumar, S.V.; Dispenzieri, A.; Lacy, M.Q.; Hayman, S.R.; Buadi, F.K.; Zeldenrust, S.R.; Dingli, D.; Russell, S.J.; Lust, J.A.; et al. Improved survival in multiple myeloma and the impact of novel therapies. Blood 2008, 111, 2516-2520. [CrossRef]

21. Anderson, K.C. Progress and paradigms in multiple myeloma. Clin. Cancer Res. 2016, 22, 5419-5427. [CrossRef]

22. Tsukune, Y.; Sasaki, M.; Odajima, T.; Sunami, K.; Takei, T.; Moriuchi, Y.; Iino, M.; Isoda, A.; Nakaya, A.; Muta, T.; et al. Incidence and risk factors of hepatitis B virus reactivation in patients with multiple myeloma in an era with novel agents: A nationwide retrospective study in Japan. Blood Cancer J. 2017, 7, 631. [CrossRef] [PubMed]

23. Oketani, M.; Ido, A.; Uto, H.; Tsubouchi, H. Prevention of hepatitis B virus reactivation in patients receiving immunosuppressive therapy or chemotherapy. Hepatol. Res. 2012, 42, 627-636. [CrossRef] [PubMed]

24. Loomba, R.; Liang, T.J. Hepatitis B Reactivation associated with immune suppressive and biological modifier therapies: Current concepts, management strategies, and future directions. Gastroenterology 2017, 152, 1297-1309. [CrossRef] [PubMed]

25. Hwang, J.P.; Lok, A.S. Management of patients with hepatitis B who require immunosuppressive therapy. Nat. Rev. Gastroenterol. Hepatol. 2014, 11, 209-219. [CrossRef]

26. Arora, A.; Anand, A.C.; Kumar, A.; Singh, S.P.; Aggarwal, R.; Dhiman, R.K.; Aggarwal, S.; Alam, S.; Bhaumik, P.; Dixit, V.K.; et al. INASL Guidelines on Management of Hepatitis B Virus Infection in Patients receiving Chemotherapy, Biologicals, Immunosupressants, or Corticosteroids. J. Clin. Exp. Hepatol. 2018, 8, 403-431. [CrossRef]

27. Sakamoto, K.; Umemura, T.; Ito, K.; Okumura, A.; Joshita, S.; Ota, M.; Sugiyama, M.; Mizokami, M.; Yoneda, M.; Tanaka, E. Virological factors associated with the occurrence of HBV reactivation in patients with resolved HBV infection analyzed through ultradeep sequencing. J. Infect Dis. 2019, in press. [CrossRef] 
28. European Association for the Study of the Liver. EASL 2017 Clinical practice guidelines on the management of hepatitis B virus infection. J. Hepatol. 2017, 67, 370-398. [CrossRef]

29. Zannella, A.; Marignani, M.; Begini, P. Hematological Malignancies and HBV Reactivation Risk: Suggestions for Clinical Management. Viruses 2019, 11, 858. [CrossRef]

30. Wang, B.; Mufti, G.; Agarwal, K. Reactivation of hepatitis B infection in patients with haematological disorders. Haematologica 2019, 104, 435-443. [CrossRef]

31. Koffas, A.; Dolman, G.E.; Kennedy, P.T. Hepatitis B virus reactivation in patients treated with immunosuppressive drugs: A practical guide for clinicians. Clin. Med. 2018, 18, 212-218. [CrossRef]

32. Sagnelli, C.; Pisaturo, M.; Calo, F.; Martini, S.; Sagnelli, E.; Coppola, N. Reactivation of hepatitis B virus infection in patients with hemo-lymphoproliferative diseases, and its prevention. World J. Gastroenterol. 2019, 25, 3299-3312. [CrossRef] [PubMed]

33. Yeo, W.; Zee, B.; Zhong, S.; Chan, P.K.; Wong, W.L.; Ho, W.M.; Lam, K.C.; Johnson, P.J. Comprehensive analysis of risk factors associating with Hepatitis $B$ virus (HBV) reactivation in cancer patients undergoing cytotoxic chemotherapy. Br. J. Cancer 2004, 90, 1306-1311. [CrossRef] [PubMed]

34. Cheng, A.L.; Hsiung, C.A.; Su, I.J.; Chen, P.J.; Chang, M.C.; Tsao, C.J.; Kao, W.Y.; Uen, W.C.; Hsu, C.H.; Tien, H.F.; et al. Steroid-free chemotherapy decreases risk of hepatitis B virus (HBV) reactivation in HBV-carriers with lymphoma. Hepatology 2003, 37, 1320-1328. [CrossRef] [PubMed]

35. Matsue, K.; Kimura, S.; Takanashi, Y.; Iwama, K.; Fujiwara, H.; Yamakura, M.; Takeuchi, M. Reactivation of hepatitis B virus after rituximab-containing treatment in patients with CD20-positive B-cell lymphoma. Cancer 2010, 116, 4769-4776. [CrossRef] [PubMed]

36. Kim, H.Y.; Kim, W. Chemotherapy-related reactivation of hepatitis B infection: Updates in 2013. World J. Gastroenterol. 2014, 20, 14581-14588. [CrossRef] [PubMed]

37. Perrillo, R.P.; Gish, R.; Falck-Ytter, Y.T. American Gastroenterological Association Institute technical review on prevention and treatment of hepatitis $\mathrm{B}$ virus reactivation during immunosuppressive drug therapy. Gastroenterology 2015, 148, 221-244.e3. [CrossRef] [PubMed]

38. Yeo, W.; Chan, P.K.; Zhong, S.; Ho, W.M.; Steinberg, J.L.; Tam, J.S.; Hui, P.; Leung, N.W.; Zee, B.; Johnson, P.J. Frequency of hepatitis B virus reactivation in cancer patients undergoing cytotoxic chemotherapy: A prospective study of 626 patients with identification of risk factors. J. Med. Virol. 2000, 62, $299-307$. [CrossRef]

39. Kim, S.J.; Hsu, C.; Song, Y.Q.; Tay, K.; Hong, X.N.; Cao, J.; Kim, J.S.; Eom, H.S.; Lee, J.H.; Zhu, J.; et al. Hepatitis B virus reactivation in B-cell lymphoma patients treated with rituximab: Analysis from the Asia Lymphoma Study Group. Eur. J. Cancer 2013, 49, 3486-3496. [CrossRef]

40. Liu, W.P.; Xiao, X.B.; Xue, M.; Wang, G.Q.; Wang, X.P.; Song, Y.Q.; Zhu, J. Prophylactic use of entecavir for lymphoma patients with past hepatitis B virus infection: A randomized controlled trial. Clin. Lymphoma Myeloma Leuk. 2019, 19, 103-108. [CrossRef]

41. Drafting Committee for Hepatitis Management Guidelines and the Japan Society of Hepatology. JSH guidelines for the management of hepatitis B virus infection. Hepatol. Res. 2014, 44 (Suppl. 1), 1-58. [CrossRef]

42. Sarin, S.K.; Kumar, M.; Lau, G.K.; Abbas, Z.; Chan, H.L.; Chen, C.J.; Chen, D.S.; Chen, H.L.; Chen, P.J.; Chien, R.N.; et al. Asian-Pacific clinical practice guidelines on the management of hepatitis B: A 2015 update. Hepatol. Int. 2016, 10, 1-98. [CrossRef] [PubMed]

43. Hwang, J.P.; Somerfield, M.R.; Alston-Johnson, D.E.; Cryer, D.R.; Feld, J.J.; Kramer, B.S.; Sabichi, A.L.; Wong, S.L.; Artz, A.S. Hepatitis B virus screening for patients with cancer before therapy: American society of clinical oncology provisional clinical opinion update. J. Clin. Oncol. 2015, 33, 2212-2220. [CrossRef] [PubMed]

44. Reddy, K.R.; Beavers, K.L.; Hammond, S.P.; Lim, J.K.; Falck-Ytter, Y.T. American Gastroenterological Association Institute guideline on the prevention and treatment of hepatitis B virus reactivation during immunosuppressive drug therapy. Gastroenterology 2015, 148, 215-219. [CrossRef]

45. Terrault, N.A.; Lok, A.S.F.; McMahon, B.J.; Chang, K.M.; Hwang, J.P.; Jonas, M.M.; Brown, R.S., Jr.; Bzowej, N.H.; Wong, J.B. Update on prevention, diagnosis, and treatment of chronic hepatitis B: AASLD 2018 hepatitis B guidance. Hepatology 2018, 67, 1560-1599. [CrossRef] [PubMed] 
46. Kusumoto, S.; Arcaini, L.; Hong, X.; Jin, J.; Kim, W.S.; Kwong, Y.L.; Peters, M.G.; Tanaka, Y.; Zelenetz, A.D.; Kuriki, H.; et al. Risk of HBV reactivation in patients with B-cell lymphomas receiving obinutuzumab or rituximab immunochemotherapy. Blood 2019, 133, 137-146. [CrossRef]

47. Tapan, U.; May, S.K.; Fiore, J.; Kozyreva, O. Reactivation of hepatitis B virus following bendamustine-containing chemotherapy in a patient with multiple myeloma. Leuk. Lymphoma 2011, 52, 916-918. [CrossRef]

48. Tanaka, H.; Sakuma, I.; Hashimoto, S.; Takeda, Y.; Sakai, S.; Takagi, T.; Shimura, T.; Nakaseko, C. Hepatitis B reactivation in a multiple myeloma patient with resolved hepatitis $\mathrm{B}$ infection during bortezomib therapy: Case report. J. Clin. Exp. Hematop. 2012, 52, 67-69. [CrossRef]

49. Goldberg, R.; Smith, E.; Bell, S.; Thompson, A.; Desmond, P.V. Bortezomib monotherapy in patients with multiple myeloma is associated with reactivation of hepatitis B. Intern. Med. J. 2013, 43, 835-836. [CrossRef]

50. Hussain, S.; Jhaj, R.; Ahsan, S.; Ahsan, M.; Bloom, R.E.; Jafri, S.M. Bortezomib induced hepatitis B reactivation. Case Rep. Med. 2014, 2014, 964082. [CrossRef]

51. Yang, J.D.; Girotra, M.; Restrepo, A.; Waheed, S.; Barlogie, B.; Duarte-Rojo, A. Hepatitis B reactivation in patients with multiple myeloma and isolated positive hepatitis B core antibody: A call for greater cognizance. Ann. Hepatol. 2014, 13, 461-465. [CrossRef]

52. Silva-Pinto, A.; Andrade, J.; Araujo, F.; Santos, L.; Sarmento, A. Reactivation of hepatitis B virus without core antibody. J. Clin. Microbiol. 2015, 53, 1434-1435. [CrossRef] [PubMed]

53. Gu, H.R.; Shin, D.Y.; Choi, H.S.; Moon, C.H.; Park, S.C.; Kang, H.J. HBV reactivation in a HBsAg-negative patient with multiple myeloma treated with prednisolone maintenance therapy after autologous HSCT. Blood Res. 2015, 50, 51-53. [CrossRef] [PubMed]

54. Danhof, S.; Schreder, M.; Strifler, S.; Einsele, H.; Knop, S. Long-term disease control by pomalidomide-/ dexamethasone-based therapy in a patient with advanced multiple myeloma: A case report and review of the literature. Case Rep. Oncol. 2015, 8, 189-195. [CrossRef] [PubMed]

55. Almaghrabi, M.M.; Fortinsky, K.J.; Wong, D. Severe acute hepatitis B in HBV-vaccinated partner of a patient with multiple myeloma treated with cyclophosphamide, bortezomib, and dexamethasone and autologous stem cell transplant. Case Rep. Hepatol. 2017, 2017, 2463953. [CrossRef]

56. Endo, T.; Sawada, K.; Fujimoto, K.; Yamamoto, S.; Takashima, H.; Haseyama, Y.; Nishio, M.; Koizumi, K.; Koike, T. Reactivation of hepatitis B virus after autologous peripheral blood stem cell transplantation in patients with positive hepatitis B surface antibodies. Rinsho Ketsueki 2000, 41, 322-328.

57. Uhm, J.E.; Kim, K.; Lim, T.K.; Park, B.B.; Park, S.; Hong, Y.S.; Lee, S.C.; Hwang, I.G.; Koh, K.C.; Lee, M.H.; et al. Changes in serologic markers of hepatitis B following autologous hematopoietic stem cell transplantation. Biol. Blood Marrow Transplant. 2007, 13, 463-468. [CrossRef]

58. Matsue, K.; Aoki, T.; Odawara, J.; Fujiwara, H.; Iwama, K.; Kimura, S.; Yamakura, M.; Takeuch, M. High risk of hepatitis B-virus reactivation after hematopoietic cell transplantation in hepatitis B core antibody-positive patients. Eur. J. Haematol. 2009, 83, 357-364. [CrossRef]

59. Ceneli, O.; Ozkurt, Z.N.; Acar, K.; Rota, S.; Aki, S.Z.; Yegin, Z.A.; Yagci, M.; Ozenirler, S.; Sucak, G.T. Hepatitis B-related events in autologous hematopoietic stem cell transplantation recipients. World J. Gastroenterol. 2010, 16, 1765-1771. [CrossRef]

60. Yoshida, T.; Kusumoto, S.; Inagaki, A.; Mori, F.; Ito, A.; Ri, M.; Ishida, T.; Komatsu, H.; Iida, S.; Sugauchi, F.; et al. Reactivation of hepatitis B virus in HBsAg-negative patients with multiple myeloma: Two case reports. Int. J. Hematol. 2010, 91, 844-849. [CrossRef]

61. Borentain, P.; Colson, P.; Coso, D.; Bories, E.; Charbonnier, A.; Stoppa, A.M.; Auran, T.; Loundou, A.; Motte, A.; Ressiot, E.; et al. Clinical and virological factors associated with hepatitis B virus reactivation in HBsAg-negative and anti-HBc antibodies-positive patients undergoing chemotherapy and/or autologous stem cell transplantation for cancer. J. Viral Hepat. 2010, 17, 807-815. [CrossRef]

62. Lee, J.Y.; Lim, S.H.; Lee, M.Y.; Kim, H.; Sinn, D.H.; Gwak, G.Y.; Choi, M.S.; Lee, J.H.; Jung, C.W.; Jang, J.H.; et al. Hepatitis B reactivation in multiple myeloma patients with resolved hepatitis B undergoing chemotherapy. Liver Int. 2015, 35, 2363-2369. [CrossRef] [PubMed]

63. Li, J.; Huang, B.; Li, Y.; Zheng, D.; Zhou, Z.; Liu, J. Hepatitis B virus reactivation in patients with multiple myeloma receiving bortezomib-containing regimens followed by autologous stem cell transplant. Leuk. Lymphoma 2015, 56, 1710-1717. [CrossRef] [PubMed] 
64. Tsukune, Y.; Sasaki, M.; Odajima, T.; Isoda, A.; Matsumoto, M.; Koike, M.; Tamura, H.; Moriya, K.; Ito, S.; Asahi, M.; et al. Incidence and clinical background of hepatitis B virus reactivation in multiple myeloma in novel agents' era. Ann. Hematol. 2016, 95, 1465-1472. [CrossRef] [PubMed]

65. Mochida, S.; Nakao, M.; Nakayama, N.; Uchida, Y.; Nagoshi, S.; Ido, A.; Mimura, T.; Harigai, M.; Kaneko, H.; Kobayashi, H.; et al. Nationwide prospective and retrospective surveys for hepatitis B virus reactivation during immunosuppressive therapies. J. Gastroenterol. 2016, 51, 999-1010. [CrossRef] [PubMed]

66. Han, J.W.; Yang, H.; Lee, H.L.; Bae, S.H.; Choi, J.Y.; Lee, J.W.; Kim, H.J.; Lee, S.; Cho, S.G.; Min, C.K.; et al. Risk factors and outcomes of hepatitis B virus reactivation in hepatitis B surface antigen negative patients with hematological malignancies. Hepatol. Res. 2016, 46, 657-668. [CrossRef] [PubMed]

67. Varma, A.; Biritxinaga, L.; Saliba, R.M.; Stich, M.; Jauch, S.F.; Afrough, A.; Honhar, M.; Popat, U.R.; Shafi, M.A.; Shah, N.; et al. Impact of hepatitis B core antibody seropositivity on the outcome of autologous hematopoietic stem cell transplantation for multiple myeloma. Biol. Blood Marrow Transplant. 2017, 23, 581-587. [CrossRef]

68. Ataca Atilla, P.; Yalciner, M.; Atilla, E.; Idilman, R.; Beksac, M. Hepatitis B reactivation rate and fate among multiple myeloma patients receiving lenalidomide and/or bortezomib containing regimens. Turk. J. Haematol. 2019, in press. [CrossRef]

69. Huang, H.; Li, X.; Zhu, J.; Ye, S.; Zhang, H.; Wang, W.; Wu, X.; Peng, J.; Xu, B.; Lin, Y.; et al. Entecavir vs. lamivudine for prevention of hepatitis $\mathrm{B}$ virus reactivation among patients with untreated diffuse large B-cell lymphoma receiving R-CHOP chemotherapy: A randomized clinical trial. JAMA 2014, 312, 2521-2530. [CrossRef]

70. Castelli, R.; Ferraris, L.; Pantaleo, G.; Lambertenghi Deliliers, G.; Cicardi, M. High rate of hepatitis B viral breakthrough in elderly non-Hodgkin lymphomas patients treated with Rituximab based chemotherapy. Dig. Liver Dis. 2016, 48, 1394-1397. [CrossRef]

71. Grossi, G.; Vigano, M.; Facchetti, F.; Labanca, S.; Loglio, A.; Dodero, A.; Montefusco, V.; Corradini, P.; Cafro, A.; Cairoli, R.; et al. Failure of long-term lamivudine prophylaxis in patients with resolved hepatitis B infection undergoing chemotherapy and allogenic hematopoietic stem cell transplantation for hematological malignancies: Two case reports. Haematologica 2017, 102, e423-e426. [CrossRef]

72. Taplitz, R.A.; Kennedy, E.B.; Bow, E.J.; Crews, J.; Gleason, C.; Hawley, D.K.; Langston, A.A.; Nastoupil, L.J.; Rajotte, M.; Rolston, K.V.; et al. Antimicrobial prophylaxis for adult patients with cancer-related immunosuppression: ASCO and IDSA clinical practice guideline update. J. Clin. Oncol. 2018, 36, 3043-3054. [CrossRef] [PubMed]

73. Buti, M.; Manzano, M.L.; Morillas, R.M.; Garcia-Retortillo, M.; Martin, L.; Prieto, M.; Gutierrez, M.L.; Suarez, E.; Gomez Rubio, M.; Lopez, J.; et al. Randomized prospective study evaluating tenofovir disoproxil fumarate prophylaxis against hepatitis B virus reactivation in anti-HBc-positive patients with rituximab-based regimens to treat hematologic malignancies: The Preblin study. PLoS ONE 2017, 12, e0184550. [CrossRef] [PubMed]

74. Picardi, M.; Della Pepa, R.; Giordano, C.; Zacheo, I.; Pugliese, N.; Mortaruolo, C.; Trastulli, F.; Giordano, A.; Lucignano, M.; Di Perna, M.; et al. Tenofovir vs. lamivudine for the prevention of hepatitis B virus reactivation in advanced-stage DLBCL. Blood 2019, 133, 498-501. [CrossRef] [PubMed]

75. Kitrinos, K.M.; Corsa, A.; Liu, Y.; Flaherty, J.; Snow-Lampart, A.; Marcellin, P.; Borroto-Esoda, K.; Miller, M.D. No detectable resistance to tenofovir disoproxil fumarate after 6 years of therapy in patients with chronic hepatitis B. Hepatology 2014, 59, 434-442. [CrossRef]

76. Fung, J.; Seto, W.K.; Lai, CL.; Yuen, M.F. Extrahepatic effects of nucleoside and nucleotide analogues in chronic hepatitis B treatment. J. Gastroenterol. Hepatol. 2014, 29, 428-434. [CrossRef]

77. Kayaaslan, B.; Guner, R. Adverse effects of oral antiviral therapy in chronic hepatitis B. World J. Hepatol. 2017, 9, 227-241. [CrossRef]

78. Lange, C.M.; Bojunga, J.; Hofmann, W.P.; Wunder, K.; Mihm, U.; Zeuzem, S.; Sarrazin, C. Severe lactic acidosis during treatment of chronic hepatitis B with entecavir in patients with impaired liver function. Hepatology 2009, 50, 2001-2006. [CrossRef]

79. Buti, M.; Tsai, N.; Petersen, J.; Flisiak, R.; Gurel, S.; Krastev, Z.; Aguilar, S.R.; Flaherty, J.F.; Martins, E.B.; Charuworn, P.; et al. Seven-year efficacy and safety of treatment with tenofovir disoproxil fumarate for chronic hepatitis B virus infection. Dig. Dis. Sci. 2015, 60, 1457-1464. [CrossRef] 
80. Wong, G.L.; Tse, Y.K.; Wong, V.W.; Yip, T.C.; Tsoi, K.K.; Chan, H.L. Long-term safety of oral nucleos(t)ide analogs for patients with chronic hepatitis B: A cohort study of 53,500 subjects. Hepatology 2015, 62, 684-693. [CrossRef]

81. Garcia-Rodriguez, M.J.; Canales, M.A.; Hernandez-Maraver, D.; Hernandez-Navarro, F. Late reactivation of resolved hepatitis B virus infection: An increasing complication post rituximab-based regimens treatment? Am. J. Hematol. 2008, 83, 673-675. [CrossRef]

82. Nakaya, A.; Fujita, S.; Satake, A.; Nakanishi, T.; Azuma, Y.; Tsubokura, Y.; Hotta, M.; Yoshimura, H.; Ishii, K.; Ito, T.; et al. Delayed HBV reactivation in rituximab-containing chemotherapy: How long should we continue anti-virus prophylaxis or monitoring HBV-DNA? Leuk. Res. 2016, 50, 46-49. [CrossRef] [PubMed]

83. McCarthy, P.L.; Holstein, S.A.; Petrucci, M.T.; Richardson, P.G.; Hulin, C.; Tosi, P.; Bringhen, S.; Musto, P.; Anderson, K.C.; Caillot, D.; et al. Lenalidomide maintenance after autologous stem-cell transplantation in newly diagnosed multiple myeloma: A meta-analysis. J. Clin. Oncol. 2017, 35, 3279-3289. [CrossRef] [PubMed]

84. Siegel, D.S.; Dimopoulos, M.A.; Ludwig, H.; Facon, T.; Goldschmidt, H.; Jakubowiak, A.; San-Miguel, J.; Obreja, M.; Blaedel, J.; Stewart, A.K. Improvement in overall survival with carfilzomib, lenalidomide, and dexamethasone in patients with relapsed or refractory multiple myeloma. J. Clin. Oncol. 2018, 36, 728-734. [CrossRef]

85. Doyle, J.; Raggatt, M.; Slavin, M.; McLachlan, S.A.; Strasser, S.I.; Sasadeusz, J.J.; Howell, J.; Hajkowicz, K.; Nandurkar, H.; Johnston, A.; et al. Hepatitis B management during immunosuppression for haematological and solid organ malignancies: An Australian consensus statement. Med. J. Aust. 2019, 210, 462-468. [CrossRef] [PubMed]

86. Nucci, M.; Anaissie, E. Infections in patients with multiple myeloma in the era of high-dose therapy and novel agents. Clin. Infect. Dis. 2009, 49, 1211-1225. [CrossRef] [PubMed]

87. Hou, L.; Zhao, J.; Gao, S.; Ji, T.; Song, T.; Li, Y.; Wang, J.; Geng, C.; Long, M.; Chen, J.; et al. Restriction of hepatitis B virus replication by c-Abl-induced proteasomal degradation of the viral polymerase. Sci. Adv. 2019, 5, eaau7130. [CrossRef]

88. Ataca, P.; Atilla, E.; Kircali, E.; Idilman, R.; Beksac, M. Hepatitis B (HBV) reactivation rate and fate among multiple myeloma patients receiving lenalidomide containing regimens: A single center experience. Blood 2015, 126, 5377. [CrossRef]

89. Ye, Z.; Jin, H.; Qian, Q. Argonaute 2: A novel rising star in cancer research. J. Cancer 2015, 6, 877-882. [CrossRef]

90. Xu, Q.; Hou, Y.X.; Langlais, P.; Erickson, P.; Zhu, J.; Shi, C.X.; Luo, M.; Zhu, Y.; Xu, Y.; Mandarino, L.J.; et al. Expression of the cereblon binding protein argonaute 2 plays an important role for multiple myeloma cell growth and survival. BMC Cancer 2016, 16, 297. [CrossRef]

91. Hayes, C.N.; Akamatsu, S.; Tsuge, M.; Miki, D.; Akiyama, R.; Abe, H.; Ochi, H.; Hiraga, N.; Imamura, M.; Takahashi, S.; et al. Hepatitis B virus-specific miRNAs and argonaute 2 play a role in the viral life cycle. PLOS ONE 2012, 7, e47490. [CrossRef]

92. Kibata, K.; Ito, T.; Inaba, M.; Tanaka, A.; Iwata, R.; Inagaki-Katashiba, N.; Phan, V.; Satake, A.; Nomura, S. The immunomodulatory-drug, lenalidomide, sustains and enhances interferon-alpha production by human plasmacytoid dendritic cells. J. Blood Med. 2019, 10, 217-226. [CrossRef] [PubMed]

93. Drgona, L.; Gudiol, C.; Lanini, S.; Salzberger, B.; Ippolito, G.; Mikulska, M. ESCMID Study Group for Infections in Compromised Hosts (ESGICH) consensus document on the safety of targeted and biological therapies: An infectious diseases perspective (agents targeting lymphoid or myeloid cells surface antigens [II]: CD22, CD30, CD33, CD38, CD40, SLAMF-7 and CCR4). Clin. Microbiol. Infect. 2018, 24 (Suppl. 2), S83-S94. [PubMed]

94. Krejcik, J.; Casneuf, T.; Nijhof, I.S.; Verbist, B.; Bald, J.; Plesner, T.; Syed, K.; Liu, K.; van de Donk, N.W.; Weiss, B.M.; et al. Daratumumab depletes CD38+ immune regulatory cells, promotes T-cell expansion, and skews T-cell repertoire in multiple myeloma. Blood 2016, 128, 384-394. [CrossRef] [PubMed]

95. Nakao, M.; Nakayama, N.; Uchida, Y.; Tomiya, T.; Ido, A.; Sakaida, I.; Yokosuka, O.; Takikawa, Y.; Inoue, K.; Genda, T.; et al. Nationwide survey for acute liver failure and late-onset hepatic failure in Japan. J. Gastroenterol. 2018, 53, 752-769. [CrossRef]

(C) 2019 by the authors. Licensee MDPI, Basel, Switzerland. This article is an open access article distributed under the terms and conditions of the Creative Commons Attribution (CC BY) license (http://creativecommons.org/licenses/by/4.0/). 